речення складає основу складних мовленнєвих актів, на цій підставі ми розмежовуємо автономні та гібридні мовленнєві тактики.

\title{
Лiтература:
}

1. Безугла Л.Р. Вербалізація імпліцитних смислів у німецькомовному діалогічному дискурсі. Харків, 2007. 332 с.

2. Сковородников А.П. О необходимости разграничения понятий «риторический прием», «стилистическая фигура», «речевая тактика», «речевой жанр» в пратике терминологической лексикографии. Лингвистика. Вып. 5: сб. статей. Смоленск, 2004. С. 5-11.

3. Формановская Н.И. Речевое общение : коммуникативно-прагматический подход. Москва, 2002. 216 с.

DOI https://doi.org/10.30525/978-9934-588-90-7-44

\section{КОНЦЕПТ «CONFINEMENT» У ФРАНЦУЗЬКІЙ ЛІНГВОКУЛЬТУРІ}

\author{
Тарасюк I. B. \\ кандидат філологічних наук, \\ доиент кафедри романської філології і перекладу \\ Запорізький наиіональний університет \\ м. Запоріжжя, Украӥна
}

В умовах пандемії COVID-19 змінюється ситуативний контекст спілкування (у термінах Ф.С. Бацевича [1, с. 337]) - обставини, у яких відбувається комунікація. Оскільки на перший план виходить феномен «confinement» - ізоляція, усамітнення, стримування, то по-новому організуються час та місце спілкування, по-новому осмислюються соціальні ролі учасників комунікації.

У французькій мові лексема confinement має три значення: 1) застаріле ізоляція (ув'язненого) - vieilli. Isolement (d'un prisonnier); 2) факт або дія вилучення, замикання (у вузьких межах) - Fait d'être retiré; action d'enfermer, fait d'être enfermé (dans des limites étroites); 3) біол. утримання живої істоти (тварини або рослини) в обмеженому та закритому середовищі - BIOL. Maintien d'un être vivant (animal ou plante) dans un milieu de volume restreint et clos [2]. Як бачимо, концептуальна або когнітивна карта (в термінах О.С. Кубрякової [3, с. 373]) французького слова confinement організована навколо концептів «isolement» («ізоляція»), 
«retiré» («вилучений»), «enfermé» («утримуваний»), «limites étroites» («вузькі межі»), які формують стійкий інтенсіонал, у якому зафіксовано загальне уявлення про утримання когось або чогось в обмеженому просторі. Підвищення частотності вживання даного слова під час пандемії спричиняє певні перетворення у концептуальній структурі, яка стоїть за ним. Це обумовлює наш інтерес до цієї теми.

Отже, об'єктом дослідження є концепт «confinement» як узагальнене уявлення носіїв французької мови про особливий режим існування в умовах пандемії COVID-19. Предметом дослідження виступають номінації зі словом confinement, як репрезентантом відповідного концепту. Наша мета - описати ознаки концепту «confinement», вербалізовані у публіцистичних текстах французьких Інтернет видань від початку 2020 року. Методика дослідження полягає у аналізі діагностичних маркерів (у термінах І.А. Стерніна, М.С. Саломатіної [4, с. 88]), які супроводжують слово confinement на рівні контексту.

Сам концепт «confinement» входить до когнітивної структури таких концептів як «isolement» (ізоляція), «quarantaine» (карантин), тому він відтворює частину їхніх ознак, які проявляються у синонімічних сполученнях, що забезпечують зв'язність тексту: être mis, être placé en confinement (à l'isolement, en quarantaine) тощо. Проте, слово confinement має свій об'єм поняття, який обумовлює його самостійність і відмінність від його синонімів, наприклад: «Plus récemment, lors de l'épidémie d'Ebola en Afrique de l'Ouest (2013-2016), des mesures de fermeture de frontières, de confinement et de quarantaine ont été imposées à plusieurs reprises» [5].

$\mathrm{y}$ висловах décréter deux semaines de confinement (оголошувати два тижні ізоляиіï), imposer les mesures de confinement (запроваджувати заходи стримування), étendre le confinement (розиирити стримування), déclarer des zones de confinement (оголосити зони стримування), еттепеr qn dans un lieu de confinement (відвести когось до місия утримання), retourner le confinement (повернути стримування), assouplir le confinement (пом'якшити утримання) значення слова confinement розуміється як сценарій, що має наступні складові: 1) «той, кого треба утримувати, ізолювати»; 2) «захід, спрямований на утримання когось», 2) «той, хто має повноваження запроваджувати, нав'язувати, оголошувати, повертати, пом'якшувати утримання, тощо». 3 боку того, хто підпадає під заходи обмеження, можливі наступні дії - s'adapter au confinement (призвичаїтись до утримання, усамітнення), sирроrter le confinement (витримувати усамітнення), transgresser le confinement (порушувати утримання), теttre à profit le confinement (скористатися обмеженням пересування) тощо.

У сполученнях з предикатами confinement може набувати: 
- оцінних ознак: «le confinement a un effet» (стримування має певний ефект), «le confinement coûte cher» (стримування коштує дорого),

- персоніфікованих ознак: «le confinement menace de mort à qn/qch» (утримання загрожуе комусь смертю), «le confinement s'est profilé» (стримування набуло форми), «le confinement a marqué l'avènement du silence» (стримування позначило прихід тиші), «le confinement a ouvert les уеих sur qch» (утримання відкрило очі на щзось).

Важливим напрямом формування номінативних одиниць зі словом confinement $\epsilon$, так звані, типологічні номінації даного феномену: le confinement à grande echelle (повномасштабне стримування), le confinement partiel (часткове стримування), le confinement à proximité des parents (утримання поряд 3 батьками) тощо. Сфера вжитку слова confinement розширюється у контекстах 3 висловом les mesures de confinement, який відкриває шлях до залучення назв заходів, що можуть розумітись як складові даного феномену: «Usines fermées, routes bloquées, tourisme volatilisé... les mesures de confinement ont un effet négatif sur l'activité industrielle, même s'il est trop tôt pour savoir si l'impact sera durable» [6].

Окремої уваги заслуговують мовленнєві номінації на основі концептуальної метафори «le confinement c'est un temps propice» (усамітнення є продуктивним часом), яка репрезентує період ізоляції, як корисний для людей, які хочуть подумати, почитати, оцінити свої дії тощо, або, для природи, яка починає відновлюватись - «le confinement, cette parenthèse enchantée où la nature a repris ses droits» [7].

Отже, дослідження текстових номінацій зі словом confinement дозволяє описати напрямки, у яких розвивається семантика цього слова, що у подальших дослідженнях дозволить зробити більш повним його лексикографічний опис.

\section{Література:}

1. Бацевич Ф.С. Основи комунікативної лінгвістики. Київ: Видавничий центр «Академія», 2004. 344 с.

2. Trésor de la langue française informatisé. URL: http://stella.atilf.fr/ Dendien/scripts/tlfiv5/advanced.exe?8;s=3158539395; （дата звернення: 25.10.2020)

3. Кубрякова Е.С. Язык и знание: На пути получения знаний о языке: Части речи с когнитивной точки зрения. М.: Языки славянской культуры, 2004. 560 с.

4. Стернин И.А., Саломатина М.С. Семантический анализ слова в контексте. Воронеж: «Истоки», 2011. 150 с. 
5. Coronavirus chinois : la quarantaine est-elle une mesure efficace pour éviter la propagation ? URL: https://www.lemonde.fr /planete/article/2020 /01/28/coronavirus-chinois-la-quarantaine-une-mesure-de-precautionancienne-a-l-efficacite-tres-relative_6027513_3244.html (дата звернення: 26.10.2020)

6. Bouissou J., Leplâtre S. L'épidémie de coronavirus a stoppé net l'économie de la Chine. URL: https:// www.lemonde.fr/ economie/ article/2020/02/04/ coronavirus-1-economie-chinoise-est-a-1-arret_6028357_ 3234.html (дата звернення: 26.10.2020)

7. Cosnard D. Le confinement, cette parenthèse enchantée où la nature a repris ses droits. URL: https://www.lemonde.fr/m-styles/article/ 2020/07/16/le-confinement-cette-parenthese-enchantee-ou-la-nature-a-reprisses-droits_6046325_4497319.html (дата звернення: 27.10.2020)

DOI https://doi.org/10.30525/978-9934-588-90-7-45

\title{
LINGUISTIC SYNTAGMATICS IN THE VERBAL CONFLICT
}

\author{
Chayka L. V. \\ Doctor of Philology, \\ Associate Professor of the Foreign Languages Department Research and \\ Educational Center of Foreign Languages \\ National Academy of Sciences of Ukraine \\ Kyiv, Ukraine
}

\section{Onuchak L. V.}

PhD in Pedagogy, Associate Professor, Head of the Modern European Languages Department

University of State Fiscal Service of Ukraine

Irpin, Kyiv region, Ukraine

The concept of verbal conflict is such a violation of the human communication process, when one of the communicants does not fully or partially understand the other, has a negative attitude to his/her manner of speech behavior, verbal-cognitive base or to the signs used in the communicative act. The verbal conflict concept provides an opportunity to generalize and theoretically comprehend the whole complex of similar phenomena of speech interaction, which were previously either studied sporadically or not included in a number of linguistic objects at all. 